\title{
Review
}

Author(s): H. B.

Review by: H. B.

Source: The Geographical Journal, Vol. 43, No. 5 (May, 1914), pp. 573-574

Published by: geographicalj

Stable URL: http://www.jstor.org/stable/1778309

Accessed: 11-05-2016 23:10 UTC

Your use of the JSTOR archive indicates your acceptance of the Terms \& Conditions of Use, available at

http://about.jstor.org/terms

JSTOR is a not-for-profit service that helps scholars, researchers, and students discover, use, and build upon a wide range of content in a trusted digital archive. We use information technology and tools to increase productivity and facilitate new forms of scholarship. For more information about JSTOR, please contact support@jstor.org.

The Royal Geographical Society (with the Institute of British Geographers), Wiley are collaborating with JSTOR to digitize, preserve and extend access to The Geographical Journal 


\section{Egyptian IrRtgation.}

'Egyptian Irrigation.' By Sir W. Willcocks and J. I. Craig. 3rd edition. 2 vols. London: Spon. 1913. Maps and Illustrations. Price 42s. net.

The third edition of this work has been brought out under the joint authorship of Sir William Willcocks and Mr. J. I. Craig, whose full qualifications for their task are set forth in the Introduction written by Sir Hanbury Brown. Irrigation is so vital and all-pervading a matter in Egypt that it is not surprising to find a wide range of subjects dealt with in the book. Geology, meteorology, physiography, agriculture, and finance are all matters of concern to the irrigation engineer as affecting his peculiar province of irrigation, drainage and land reclamation. Therefore all these subjects are duly discussed. Two chaptersii. and iii.-dealing with the hydrology of the Nile, constitute an interesting and valuable geographical record, and contain figures, relating to discharges, levels and the dimensions of channels, of the greatest value to those whose duty it may be to work out projects for the further development of the resources of the Nile.

The next two chapters-iv. and v.--are devoted to basin irrigation. Much of their contents is interesting as past history, but has ceased to convey lessons for the future in consequence of recent developments. Since the Aswan dam was built, the greater part of the Middle Egypt basins has been converted to land perennially irrigated, so that the formidable operations of filling and emptying this formerly extensive system of basins are things of the past. Moreover, the conditions affecting the basins which remain unconverted, have been much improved by the construction of the Assiut barrage, and also by the reduction of the area to be served. The conditions also of basin irrigation in the more southerly provinces have been made more favourable by the construction of the Esna barrage. It seems almost a pity that the publication of this work was not delayed two or three months, so that the levels of the abnormally low flood of 1913, and the beneficial effect of the Nile barrages on such unprecedentedly low levels, might have been placed on record therein.

At the present stage of Egypt's development, perhaps the most important problem is that of drainage and land reclamation, which is discussed in chapter vii. It is accepted by all that the low-lying lands of the north of the Delta cannot be efficiently drained, or even drained at all, without pumping. The problem of providing efficient drainage to all lands in the Delta is complicated by the necessity of also providing a liberal supply of rich flood water to them. Anxiety is expressed on the ground that the project adopted by the Egyptian Government makes inadequate provision for this necessary flood-water supply, and also contemplates the extravagant proceeding of pumping a large proportion of escape and drainage water which gravitation is ready to dispose of gratis if its services are accepted.

Interesting chapters dealing with the most important Nile works will be found in volume 2. On the concluding pages of chapter xii. will be found proposals for the further husbanding of the Nile waters. The projects discussed are of great interest and importance. The proposal to scrap the Aswan dam and to substitute for it a higher one will probably receive little support, at any rate from the generation to which the author of it belongs. This has probably been realized, as an appeal is made to " posterity" to adopt the graceful cornices inspired by Egyptian skies and temples rather than the bald copings born of memories of Stonehenge under the depressing influence of London fogs.

Sir W. Willcocks has naturally much to say about the Aswan dam, of which 
the original designs were prepared by him. His criticisms of "the Raised Dam" have been contested in the pages of the Engineer during 1913, and matters of fact are in dispute. Apart from the controversial matter, however, 'Egyptian Irrigation' is a storehouse of information stocked by men of undoubted capacity, where the irrigation engineers of Egypt, and others too, will find all that they need to know to best prepare them for the teachings of experience.

H. B.

\section{AMERICA.}

\section{MounT MoKinley.}

'The Conquest of Mount McKinley.' By Belmore Brown. New York and London : G. P. Putnam's Sons. 1913. Maps and Illustrations. Price 15s. net.

The author of this fascinating book of travel objects, at starting, to the name of one who never saw Alaska being given to the highest mountain in North America. All good geographers will agree with him. The simplest method of removing the objecțion would be to call it by some other name-a suggestion which may well be left to the American Geographical Society. ${ }^{*}$ It is not easy for Swiss and Himalayan mountain climbers to realize the extraordinary difficulties involved in the attainment of an altitude such as that of Mount McKinley (20,300 feet) under Arctic conditions, and in such surroundings as those presented by the Alaskan range. Three attempts were made, two of which, in 1906 and 1910 respectively, were directed against the southern face of the mountain, and ended in failure. The southern approaches were found to be impassable. Incidentally, the exact position reached by Dr. Cook in the first expedition, when he claimed to have reached the summit, was identified; and his claim to be the first to surmount America's highest peak was thereby disposed of for good. The third expedition in 1912 was successful, and Mr. Belmore Brown, with two companions, did eventually reach the summit ridge of Mount McKinley, after almost incredible exertions. It seems ungracious to refer to the fact that they did not actually stand on the top of the highest "dome," although they were but a few minutes' walk from it. The terrific violence of the Arctic blizzard which met them on the summit when absolutely exhausted with the strenuous efforts of the climb obliged them to huddle together in the lee of that last rise, and finally to retreat hastily whilst strength was left in them to reach their 15,000 feet camp. "The most conservative of our estimates," says Brown, "of the climatic conditions we fought against was a wind of 55 miles an hour and a temperature of $15^{\circ}$ below zero." Frost particles were driven right into their clothing. This last ascent was made from the northern side of the mountain, and as the explorers started from Cook's inlet on the south, following the course of the Susitna river, it involved crossing the Alaskan range before a possible way to the summit was opened up. The interest of the book lies not only in the picturesque and fascinating descriptions of Arctic sport and travel with which it abounds, but in the very careful details of the equipment and arrangements necessary to enable explorers to tackle a wilderness of untrodden mountain country where every pound of food and every article of equipment has to be carried on their backs. Dogs and sledges were infinitely useful as far as they could go, and some of the best stories in the book are concerned with this method of travelling; but the actual mountaineering over unexplored ice-

* Archdeacon Stuck, whose ascent to the actual summit was described in the Journal for January (p. 83) and whose narrative has since appeared in book form, pleads for the retention of the native name "Denali." 